Journal of Teacher Education for Sustainability, vol. 18, no. 2, pp. 105-118, 2016

\title{
Preconditions for Sustainable Changes in Didactics Applying Self-Directed Learning in the General Education School
}

\author{
Ausra Kazlauskiene, Ramute Gaucaite and Rasa Poceviciene \\ Siauliai University, Lithuania
}

\begin{abstract}
Implementation of the result-oriented (self-)education paradigm in the general education school requires sustainable changes in didactics not only on the strategic document plane but also in educational practice. However, its implementation in practice is complicated. The success of the interaction between theory and practice largely depends on the teacher's professionalism. Therefore, the insights that have emerged in the context of teachers' practical experiences applying self-directed learning are important identifying preconditions for sustainable changes in didactics. The semi-structured written survey and the content analysis enabled the authors to find out preconditions for changes in didactics, manifesting themselves through the teacher"s personal self-actualisation, the student's empowerment to learn and redistribution of powers of participants of the educational process. Research results suggest that identified preconditions for changes in didactics are interrelated and illustrate manifestation of sustainable changes in didactics.
\end{abstract}

Keywords: self-directed learning, didactics, (self-)education process

Education and improvement of quality of education remain the priority aims of the national policy. One of the aims of the National Strategy on Education for the years 2013-2022 (The National Strategy on Education for the years 2013-2022) is to improve quality of education, which is not accidental because according to international research results (Trends in International Mathematics and Science Study (TIMSS), Progress in International Reading Literacy Study (PIRLS)), in spite of all efforts, students' literacy in Lithuania is worsening (TIMSS 2015 Assessment Frameworks; PIRLS 2016 Assessment Framework).

In the success trajectory simulated at the National Progress Strategy "Lithuania 2030" (The National Progress Strategy "Lithuania 2030"), the most important role is given to the society's education: education of the society must enable us both to bravely face new challenges and manage them. However, many recent studies list a number of educational problems: "the current system of education is rigid, too little attention is paid to enhancement of critical thinking abilities, students are sufficiently encouraged to create and implement ideas. Often teaching programmes are based on repetition, 
they do not stimulate thinking, analysis and creative processes" (The National Progress Strategy "Lithuania 2030", p. 4).

In education, reorienting to the result-oriented (self-)education paradigm (Rethinking Education: Investing in Skills for Better Socio-Economic Outcomes, 2012; Shewbridge, Godfrey, Hermann, \& Nusche, 2016), approaches of didactics are also essentially changing. In Lithuania, the necessity for such systemic changes at the strategic level is perceived and recorded in the main documents governing education (LR Law on Education, 2011; Good School Concept, 2015), but in the educational practice its implementation is complicated.

The study of the National Agency for School Evaluation (Quality of Activity of General Education Schools, 2015) demonstrated that the majority of Lithuanian schools could not adapt quickly and their curricula were focused on students' knowledge and development of academic abilities. Assessment of students' attainments and application of feedback in education remain the most problematic lesson components. Meanwhile, studies have shown that higher educational attainments are more determined by feedback, meta-awareness, the ability to manage one's learning and the like (The Teaching and Learning Toolkit, 2014). Slightly better evaluated areas are only the ones that are directly unrelated to the (self-)education process (social partnership, traditions, and rituals, etc.). In addition, studies conducted on teaching aids (textbooks) demonstrate that the latter are prepared regardless of the diversity of students' learning styles, are not suitable for individualisation and differentiation of learning; therefore, it is difficult to apply them for students' independent learning (Bernotiene, Briediene, Gerulaitis, Gutauskaite, Zaukiene, \& Jasinauskas, 2014).

One of the instruments that helps implement manifestation of result-oriented paradigm in educational practice can be self-directed learning (Blaschke, 2012; Dick, 2013; Ehlers, 2013; van Velzen, 2016), because the identified key aim of the twenty-first century education is not only to teach students to learn but also to self-manage their learning (Brown, 2011; Gaucaite, Kazlauskiene, \& Poceviciene, 2012; Gros, Kinshuk \& Maina, 2016; Helmke, 2012; Kazlauskiene, Masiliauskiene, Gaucaite, \& Poceviciene, 2010; Thomas, Trilling, \& Fadel, 2009). The said strategic documents regulating education, approved in Lithuania, state that (self-)education should be based on selfdirected teaching and learning.

Identified disadvantages of quality of education and challenges of coping with them are systemic in nature, while the success of their implementation largely depends on the teacher. According to Bagdziuniene, et al. (2014), analysing factors of improving quality of education, researchers repeatedly provide evidence that the teacher's professionalism has a greater impact on students' learning compared to curricula, learning environment, funding, number of students in the classroom or parents (Barber \&, Mourshed, 2007; Hattie, 2009; Stronge, 2010). In practice, changes in didactics are based on the interaction between theory and practice. This provokes the use of specific educational strategies or systems (in this case, self-directed learning) and practical implementation of result-oriented education ideas. Insights that have emerged in the context of practical experiences of participants of the educational process are significant not only for making generalisations and episodic adjustment of processes but also for identifying preconditions for sustainable changes in didactics.

In order to enable the teacher to more effectively change educational practice, it is proposed to view this change as a sustainable process. Education for the 21 st century 
should follow societal goals and support individuals and communities in sustainable ways of living, decision-making and actions (Delors, et al., 1996). The primary goals of ESD are the need to ensure human dignity in all aspects of life and to build respect for other cultures and next generations in a context specific way. To achieve these goals, it is necessary to transform teaching and learning processes at all educational levels (Tilbury, 2011). This requires the development and application of new educational principles based on active and participative approaches to learning and teaching, and consequently also complex transformation of the entire educational system from its policies and priorities, principles to curricula and teaching learning activities in the classroom (Kapitulčinova et al., 2015). Such transformations and sustainable development require systemic thinking (Tilbury, \& Mula, 2009).

ESD competences combine the demand for ability to act (a desired educational goal) with the understanding of why and how to act so that crucial problems of today are addressed (desired societal goal). The concept of competence is based on holistic and future oriented thinking; in practice, it should underpin decision-making structures, especially competences such as critical weighting of viewpoints and possibilities, clarification of values and commitment to engage and undertake risk. To address the need for competences and to establish adequate learning processes, educators need the ability to plan innovations in their own teaching, to become self-directed teachers, able to set pedagogical goals related to sustainable development and adjust their teaching accordingly. This moves ESD pedagogy to a new level as opposed to traditional teaching where improved competences are typically expected to be acquired by students while educators only deliver knowledge (Kapitulčinova et al., 2015; Pipere, Salite, \& Veisson, 2015).

The review of empirical research data and documents show that implementation of the result-oriented (self-)education paradigm requires sustainable changes in didactics not only on the plane of strategic documents but also in educational practice. This leads to a more detailed analysis of the scientific problem: What preconditions for sustainable changes in didactics emerge, applying self-directed learning in educational practice?

The aim is to identify the preconditions for sustainable changes in didactics analysing teachers' approach to application of self-directed learning in the educational process.

\section{Research Methodology}

The preconditions for changes in didactics are disclosed on the basis of the following approaches:

- to actualise preconditions for didactic changes through the principle of sustainability that moves ESD pedagogy to a new level, as opposed to traditional teaching where improved competences are typically expected to be acquired by students while educators only deliver knowledge (Kapitulčinova et al., 2015; Pipere, Salite, \& Veisson, 2015);

- in this study self-directed learning is perceived as learning, in which learners find out their own learning needs, set goals and objectives, plan learning, create or choose learning environment and measures to afford adequate learning strategies, self-evaluate achievements and progress, continuously reflect and provide constructive arguments (Gaucaite, Kazlauskiene, \& Poceviciene, 2012). 


\section{Data Collection}

Data were collected using a semi-structured written survey (Turner, 2010) that enabled the authors of the present research to identify the preconditions for changes in didactics using teachers' experiences of applying self-directed learning in the (self-) educational practice. During the course of the research, the researchers had a possibility to supplement data without referring to preconceived theories about data (Brinkmann, \& Kvale, 2014). As teachers had a possibility to apply self-directed learning approaches in the educational process throughout the whole school year, it enabled the researchers to foresee topics and problems to be investigated during the survey in advance. The instrument of the written survey consisted of four open issues: distinguishing of indication of changes that took place in the teacher's teaching process; distinguishing of indication of changes in students' learning process; identification of arising barriers; projection of one's as a teacher further steps. Survey questions were designed based on Rithie and Lewis' (2003) methodological recommendations and the following principles: comprehensibility, clarity, and ease (Brinkmann, \& Kvale, 2014). Each research participant was introduced to the purpose of the survey and its questions; the course of the survey was discussed, and confidentiality was assured.

\section{Data Analysis}

Data analysis was conducted employing the content analysis method, combining the analysis of meaning and the qualitative content analysis (Mayring, 2014). The qualitative data analysis software "Kokybis" (version 0.1.0) was used that allowed identifying the analysed qualitative characteristics (Bitinas, Kazlauskiene, \& Jazgevicius, 2012). Respondents' answers were grouped by semantic-lexical similarity. These data groups were named (nomination of categories), giving the name that reflected the essence.

\section{Research Participants}

Throughout the whole school year, general education school teachers worked systematically applying (self-)directed learning in the (self-)educational process: each month, teachers, students, parents had training seminars on specific topics, which they later tried out practically in subject lessons. Teachers could consult advisers and discuss their successes and failures in subsequent training seminars. The research involved 28 teachers representing all subjects at the basic stage of education (5-8 forms).

Research ethics was based on the following principles: anonymity (research participants were assured that their personal information would not be announced; during the written survey, they were not asked to write personal data); confidentiality (respondents knew that their unbroken texts would not be distributed, they would be transcribed and presented in a generalised form for scientific purposes; safety of access to primary sources would be ensured). 


\section{The Analysis of Manifestation of Preconditions for Changes in Modern Didactics}

Throughout the whole school year, applying the self-directed learning in the educational process, respondens had to summarise changes in their experience organising the said process. It was identified that the change was oriented to the teacher and the process taking place (Fig. 1).

\begin{tabular}{|c|c|c|}
\hline \multicolumn{3}{|c|}{ How did teachers' teaching practice change? } \\
\hline $\begin{array}{l}\text { Changes oriented to } \\
\text { the teacher }\end{array}$ & $\begin{array}{l}\text { Changes oriented to } \\
\text { the process }\end{array}$ & $\begin{array}{l}\text { Changes did not take place or } \\
\text { were insignificant }\end{array}$ \\
\hline $\begin{array}{l}\text { - Changes in personal } \\
\text { features; } \\
\text { - Changes in } \\
\text { the teacher's attitude to } \\
\text { teaching and learning; } \\
\text { - Changes in the } \\
\text { teacher's attitude to } \\
\text { the student; } \\
\text { - Attention to the } \\
\text { analysis of one's } \\
\text { activities. }\end{array}$ & $\begin{array}{l}\text { - Maintaining students' independence; } \\
\text { - Changes in goal setting; } \\
\text { - Changes in planning learning; } \\
\text { - Changes in students' self-evaluation } \\
\text { possibilities; } \\
\text { - Changes in questions and questioning; } \\
\text { - Diversity of methods involving students; } \\
\text { - Organising learning according to the style } \\
\text { - Organising learning according to the } \\
\text { student's experience and abilities; } \\
\text { - Maintaining of learning motivation; } \\
\text { - Acquiring new knowledge, learning new } \\
\text { technologies. }\end{array}$ & $\begin{array}{l}\text { - Always worked like } \\
\text { that; } \\
\text { - Cannot indicate } \\
\text { features. }\end{array}$ \\
\hline
\end{tabular}

Figure 1. Changes in teachers' attitude and activities (teachers' opinion, $\mathrm{N}=28$ )

The topic: Changes oriented to the teacher. Training seminars and trying out of practical tasks, which took place during application of self-directed teaching in the educational process, presupposed changes in the very teacher as a personality: "I became braver allowing not only the strong students to work in a self-directed way." [14]; "I started treating noise in the classroom differently: if you want students to express their thoughts, share them, noise is inevitable; thus, I am no longer stressed due to it." [7]. Teachers became more self-confident, braver choosing (self-)education methods, creating conditions for students to learn and manage their learning process on their own. Teachers became open to changes and innovations as well as to certain unexpected situations that naturally might occur when the process was being created here and on purpose rather than implemented exactly according to some pre-established pattern. These are changes that take place with most difficulty but are most significant for changes in the teacher's activity; after all, the person behaves and acts the way he/she thinks. Research results showed that teachers who worked according to this system acknowledged that their attitude to the very teaching and learning as a process had changed: "I always treated students' learning as taken for granted: how to learn if you don't learn? But during the seminars I have realised that children's learning depends on everyone: both children 
and teachers, that it is not only the child on whom everything depends, maybe even more depends on the teacher. More confidence in students resulted in their increased willingness to perform assignments" [27]; "I pay more attention to students' cognition, organisation of students' activity in the lesson and the like. Earlier, perhaps I paid more attention to the way I would like to give a lesson, whether I would be able to deliver everything." [10]. It is important to emphasise that the teacher organising the students' activities according to the approaches of self-directed learning began focusing not on himself / herself or the subject content, which he / she needed to deliver to the students during a certain period of time, but on what and how the student should and could assimilate teaching materials, how long it could take and in what ways he / she can do his/her best and the like. This takes place only having acknowledged the student's personal qualities and experience as values that are important for education. These changes presuppose changes in the attitude of part of teachers to the very pupil. They began to trust that the student is a learner who can learn independently and not only according to the teacher's instructions and under his / her control ("First, I started to trust students more that they themselves can learn if I organise work well...." [22]). Trust in each other allowed for more active manifestation of collegial relationship sharing responsibilities (".... relationships with students slightly changed: there were more collaboration, discussions; students felt more responsible for their learning outcomes, learned to evaluate and evaluate themselves" [20]). Changes in the attitude to the student as a self-directed learner resulted in changes in the teacher's personal qualities ("I became braver allowing not only the strong students to work in a self-directed way" [14]).

Creation of conditions for students to experience their learning experience and for teachers to experience both their students' and their own as teachers' teaching and learning experience ("I have started paying more attention to reflection on how I work myself, whether I am more "feeding students with a spoon" or they work independently. I am observing students how dependent or self-directed they are, I note all of it in my notes...”[3]) opened up the possibility to actualise and acknowledge personal features of the student as a person and a learner, recognise experience as an educational value, and change the very learning as a process. At the same time, the very teacher's personal learning experience was changing.

To summarise the range of changes related to the teacher's personality, it can be assumed that students' teaching and learning to manage their own learning created preconditions for manifestation of the very teacher's personal learning management experience. In addition to educational goals, teachers set goals of teaching to learn, more often reflected on their activities, shared their experiences with other teachers, etc. This is another value that has additionally opened up, applying self-directed learning in the lesson.

The topic: Changes oriented to the process. Due to the limited scope of the article, it can only be mentioned that changes in the teacher's attitude to learning as a phenomenon, to the student, his / her activities at school influenced changes in the organisation of students' learning. It is a pledge for transition from the teaching paradigm to the learning paradigm. The analysis of teachers' reflections highlighted changes in the learning process, manifesting themselves through changes in the very teacher's and students' actions and activities. As it can be seen from the subsystems concretising the topic changes in the learning process, presented in Fig. 1, they encompass key components of the education process. Teachers' reflections highlighted that students were provided with 
conditions for independence, supporting their initiatives, trusting them. This manifested itself in creation of possibilities for students to set their learning goals, foresee ways of seeking them, self-evaluate the results in the context of the aim of learning. This was determined by the fact that the teacher had to change lesson plans, integrating components of students' learning to manage their learning, i.e., to plan students' learning (not only learning), leaving possibilities for them to choose, decide, make mistakes, search for solutions, get/give feedback, evaluate themselves, etc. As it has already been mentioned analysing the first topic, in lesson planning the teacher focuses not on what he / she will do in the lesson but on what and how students will do.

As it was noticed by teachers, this was a time-consuming process; therefore, organisation of such learning also required certain organisational changes (e.g., extension of perception of time frame of the lesson). It is also important to note that teachers emphasised that organisation of such teaching and learning resulted in students' higher motivation ("Students are working more, they cooperate, their activities are more independent. Students are more interested in the subject, they willingly take action themselves, I no longer have to prove them constantly how important this is" [23]). Ensuring possibilities of choice, conditions were created to assume responsibility for achieved results ("...The student becomes an active participant of the (self-)education process who is responsible for his / her learning. The student's dependence on the teacher becomes much less..." [13]). This way, motivation turns not into the aim but into the consequence, when students perceive what and what for they are doing since choices are made by themselves.

Freedom and responsibility in the self-directed learning system presuppose both possibilities for students to make responsible choices and decisions with regard to their learning and its management and clear redistribution of the teacher's and students' responsibilities. The results of the empirical study demonstrated changes in the teacher's role in the teaching and learning process. This, in turn, suggests that in the context of changes the very teacher's attitude towards the student is changing: confidence in the student as a learner is increasing.

At the same time, giving freedom and responsibility in the teaching and learning process also creates trust-based relationships between the teacher and students as well as among students themselves. On the other hand, the increase of confidence enhances the attitude to give the students more freedom while making decisions related to management of their learning.

This also changed the teacher's role: the teacher became more as a mediator between knowledge and the student, creating a certain support system. This creates conditions to organise students' learning considering the student's individual experience and abilities, the individual learning style and to base the teaching and learning process on them ("Students are provided with favourable environment to disclose their experience in the lesson, which is the basis for creation of new knowledge, enabling students to teach each other, to present their individual experience." [5]).

Teachers noticed changes in assessment strategies: more opportunities were left to the very students to evaluate themselves, reflect on results, projecting further improvement possibilities ("Improved goal setting in the lessons, the division of the goal allowed students to plan their learning in the lesson; not only I evaluated, there were more possibilities to self-evaluate one's knowledge and achievements, identifying where they succeeded and were they didn't, what and how something could be learned, where the gaps were, analyse all of it." [16]). Such (self-)evaluation becomes important to the very 
learner as a feedback form, here and now foreseeing further steps; it is not limited to its numerical expression, which is often important for educators, parents but not for the very learner. In addition, such evaluation allows assessing the very student's progress, is focused on the learner's improvement possibilities rather than his / her comparison with others.

During application of self-directed teaching in the educational process, teachers were offered a diversity of methods, while their practical application was also expressed in teachers' reflections ("...I used more diverse methods in the lesson, I learned to use more diverse software, acquired new psychological knowledge.” [4]). The teachers' efforts to promote students' analytical thinking by asking more open-ended questions, provoking the learners to actively give questions also showed up (".... I am trying to ask Why? How? more often in the lesson. Students also ask more often, they are not afraid of asking qustions” [3]).

The teacher's confidence in students and self-confidence allowed for manifestation in students' possibilities related to learning and managing their learning. Teachers' reflections highlighted students' increased possibilities to set goals, to pursue implementation of goals by planning activities, to self-evaluate their knowledge, to find out what still needs to be learned, etc. ("Improved goal setting of the lesson, the division of the goal allowed students to plan their learning in the lesson, self-evaluating their knowledge and achievements, foreseeing what else still can be learned" [16]).

It was also stated that the change had not taken place or had changed insignificantly ("Because I am constantly learning and improving, I can state that my learning in the class has not changed due to that." [1] "Changes are insignificant, maybe it has become more interesting to work, but I cannot indicate any distinct features." [17]). Since reasons of such attitude were not investigated and links with answers to other questions were not analysed, there were no possibilities to interpret these statements in more detail.

It can be assumed that implementation of self-directed learning in the educational process at school changed both the teacher's and students' activities. The presence of these changes requires changes in the very teacher's personality: this is one of the key factors of implementing the self-directed learning system at school; i.e., the teacher's perception of the (self-)education process determines the degree to which he / she will allow students to be self-directed, the extent to which he / she will be willing to share responsibilities with students, their parents and the like. This is a sustainable (systemic) change when components of the change determine each other and changes in one of them result in changes in others: changes in the teacher's attitude determined changes in the very process of (self-)education.

The fact that the attitude of the participants of the learning process is a significant factor implementing the idea of self-directed learning in the lesson is also demonstrated by the analysis of factors ensuring its application (Fig. 2). 


\begin{tabular}{|c|c|c|c|}
\hline \multicolumn{4}{|c|}{ What is required to implement the idea of self-directed learning in the lesson? } \\
\hline $\begin{array}{l}\text { Factors depending on } \\
\text { the teacher }\end{array}$ & $\begin{array}{l}\text { Factors depending on } \\
\text { the student }\end{array}$ & $\begin{array}{c}\text { Interaction of } \\
\text { participants of the } \\
\text { educational process }\end{array}$ & $\begin{array}{c}\text { Changes in the } \\
\text { physical environment }\end{array}$ \\
\hline $\begin{array}{l}\text { - Positive attitude; } \\
\text { - Initiative and } \\
\text { willingness of } \\
\text { the teacher; } \\
\text { - Being self-directed; } \\
\text { - New knowing, } \\
\text { experience; } \\
\text { - The ability of time } \\
\text { management. }\end{array}$ & $\begin{array}{l}\text { - Activeness; } \\
\text { - Motivation; } \\
\text { - Experience of being } \\
\text { able to manage one's } \\
\text { learning. }\end{array}$ & $\begin{array}{l}\text { - Joint aims, } \\
\text { endeavours; } \\
\text { - Mutual } \\
\text { understanding, trust; } \\
\text { - Communication, } \\
\text { collaboration; } \\
\text { - Joint experiences. }\end{array}$ & $\begin{array}{l}\text { - The lesson without } \\
\text { strict time limits; } \\
\text { - To use existing } \\
\text { spaces more } \\
\text { effectively. }\end{array}$ \\
\hline
\end{tabular}

Figure 2. Factors ensuring implementation of self-directed learning in the lesson (teachers' opinion, $\mathrm{N}=28$ )

As in the context of this research changes in teachers' attitude are considered most important, we will analyse the topic factors dependent on the teacher in more detail. Reflecting on changes, teachers noticed that instead of the formerly dominating attitude of "blaming" the external environment (educational policy, system and the like), unmotivated students, administration and the like for learning failures, teachers began to think more about themselves as teachers, go deep into their role as an important factor of organising the (self-)educational process, which determined success of the implemented self-directed learning model. The attitude that success depends on the teacher's positive attitude, thinking was proven ("Students' positive thinking." [9]; "Not to be afraid of experimenting, to believe in success, to provide possibilities for each student to experience success and rejoice together" [20]). It is important that the teacher should not be afraid of experimenting, making mistakes and, most importantly, believing in success because having encountered first difficulties in the educational practice, the set goals are often refused. The teacher's initiative and wish are also positioned as a component ensuring successful organisation of self-directed teaching and learning ("Knowledge, initiative and wish are needed" [3]; "Wish, responsibility for oneself and others, love for work" [15]; "The wish to work differently, innovatively, to teach students to learn" [18]). These initiatives are expressed together with the condition of assimilating new knowing, manifesting itself by new knowledge about self-directed learning, its organisation ("Knowledge is needed; new sources of information are sought..." [7]). Constant interest in what is happening, openness to innovations actualise the need for the very teacher to be self-directed ("Motivated, self-directed students and self-directed teacher" [17]) because only then the self-directed student can be educated.

Teachers distinguish the factor of time and experience as one of the conditions for successful implementation of self-directed learning ("You need twice as much time to prepare for the lesson and you need experience. Having delivered some lessons, you cannot say that you are working in an innovative way and everything works" [18]). 
Time input increases putting more efforts because you have to prepare for those lessons, think over strategies enabling the students to act in a self-directed way ("You need a lot of teacher's efforts preparing for the lesson" [1]).

It is important to note that teachers treat the student's features and experience as an important constituent of successful implementation of self-directed learning. The teacher sees positioned qualities in the student's person as already brought "from somewhere" and that such student is not an aspiration but an initial starting point. The student's activeness, curiosity, motivation, self-directed learning experience are treated as particularly important features of the student who is able to learn in a self-directed way ("Active and curious students' efforts, motivated students" [1]; "Students' motivation, abilities, skills to independently set goals and implement them on the basis of existing experiences." [5]; "Willingness to learn." [6]; "It is necessary to have more selfdirected students in the class." [13]). Such teachers' expressed attitudes, which are related to students of the corresponding culture, slightly contradict to the idea of implementation of self-directed learning: this presupposes the idea that if we already had such students, it would probably be not necessary to look for ways how to educate them in order to be such because self-directed learning is an aspiration of the self-directed learning system. Apparently, it is difficult for educators to refuse the traditional attitude settled in the educational practice that the ability to learn is only the matter of the students.

Teachers treat the interaction of the participants of the educational process and teacher-student team activities as a success factor that allows co-reaching the set goals and sharing joint experiences ("Not to be afraid of experimenting, believing in success, enabling each student to experience success and to rejoice together. A friendly atmosphere in the classroom. The teacher and students are tantamount partners, share success. Mistakes are treated as the possibility to improve." [20]). As we know, nothing brings team members together better than the possibility to share experiences, celebrate success and evaluate reasons of failure. This enhances confidence in each other, gives more selfconfidence and confidence in other person's powers, makes learning more attractive, while new knowledge constructed on the emotional basis is deeper and long-lasting.

Analysing difficulties experienced in the process of applying self-directed teaching in the educational process, in addition to lack of subject knowledge and practical skills teachers pointed out that it was most difficult to change the teacher's and the student's approach to learning ("It is most difficult to change the students' settled attitude that they are learning not for a mark but for development of their personality. Students find it difficult to get rid of tension, fear of making mistakes, and it is difficult for the teacher to change the attitude (not to look for mistakes but rather try to see good things, treating mistakes as an opportunity to improve. This is difficult and takes long to achieve." [20]). This suggests that teachers perceive the importance of the attitude of each participant of the educational process in the transition to a different (i.e., self-directed) learning and inevitability of processuality and durability of its implementation in practice. Besides, the necessity of changes in the attitudes of teachers, students and other actors of the educational process is actualised ("The self-directed learning process can lead to dissatisfaction of the administration about not that constrained students' behaviour during lessons." [12]; "It may seem to some "stricter" parents and teachers that the teacher listens to students' opinions too much, indulges them, writes too little marks, particularly unsatisfactory, for non-performed assignments, etc." [22]). 
The fact that it is difficult to change the attitude is illustrated by educators' doubts about selection of orientation of the educational process ("A large share of students prefer the traditional teaching principle because this way they learn more. If you want to make it more interesting and playful, self-directed learning suits well, but it becomes difficult if you seek more knowledge - often this teaching does not answer the purpose." [11]). The latter doubts can be avoided not setting "playfulness" against knowledge but connecting them into one whole - to enhance new knowing with positive experiences, which is regarded as one of the fundamental bases for high learning motivation.

\section{Conclusion}

1. Changes in didactics in practice are based on the interaction between theory and practice, while the success of this interaction largely depends on the teacher's professionalism. Therefore, through self-directed learning as a way of practical manifestation of result-oriented educational ideas teachers' practical manifestation experiences are actualised as significant in identifying preconditions for changes in modern didactics.

2. In order to enable the teacher to more effectively change educational practice, it is proposed to view these changes as a sustainable process, which moves ESD pedagogy to a new level, as opposed to traditional teaching where improved competencies are typically expected to be acquired by students while educators only deliver knowledge.

3. Applying self-directed learning in educational practice, preconditions for changes in didactics showed up through:

- the teacher's personal self-actualisation that is determined by changes in the teacher's attitudes, which enable possibilities to provide actual practical manifestation to the theoretical conception of result-oriented educational process in educational practice and to simulate students' learning process coping with challenges significant for didactics;

- redistribution of powers of participants of the educational process sharing responsibilities for learning (the teacher's perception of the (self-)educational process determines to what extent the teacher will allow students to be selfdirected);

- the student's empowerment to learn, when: an integrated approach to the meaning, value and manifestation of the learner's freedom, responsibility, confidence in the educational process is followed; planning of the educational process is focused on the learner and not the teacher; motivation to learn is acknowledged as a consequence of perceiving meaningfulness of self-education rather than the end in itself; combined feedback strategies are applied, aimed at the very students' initiatives to seek progress in learning.

4. Research results suggest that highlighted preconditions for changes in didactics are interrelated: changes in one of them lead to changes in others; e.g., the change in the very teacher's approach to the learner is followed by changes in the (self-) education process. On the other hand, changes in the process further lead to changes in the teacher's attitude. These links illustrate manifestation of sustainable changes in didactics. 


\section{References}

Bagdziuniene, D., Kazlauskiene, A., Liniauskaite, D., Nasvytiene, D., Sakadolskiene, E., \& Seckuviene, H. (2014). Evaluating the motivation of students to become teachers during admission into education-related study programmes. Pedagogy, 113(1), 28-44.

Barber, M., \& Mourshed, M. (2007). How the world's best-performing school systems come out on top. London: McKinsey and Company.

Bernotiene, R., Briediene, D., Gerulaitis, S., Gutauskaite, A., Zaukiene, A., \& Jasinauskas, L. (2014). Ataskaita apie dabartinę bendrojo ugdymo dalyku vadovéliu situacija. Vilnius: Ugdymo plettotès centras. Retrieved from http://www.upc.smm.lt/ ekspertavimas/vadoveliai/medziaga/tyrimai/Ataskaita_apie_bendrojo_ugdymo_ dalyku_vadoveliu_situacija.pdf

Bitinas, B., Kazlauskiene, A., \& Jazgevicius, A. (2012). The open-source program for qualitative research "Kokybis". Siauliai: VsI Siauliu universiteto leidykla.

Blaschke, L. M. (2012). Heutagogy and lifelong learning: A review of heutagogical practice and self-determined learning. International Review of Research in Open and Distance Learning, 13(1), 56-71.

Brinkmann, S., \& Kvale, S. (2014). InterViews: Learning the Craft of Qualitative Research Interviewing. London: SAGE Publications.

Dick, B. (2013). Crafting learner-centred processes using action research and action learning. In Steward Hase \& Chris Kenyon (Eds.), Self-determined Learning: Heutagogy in Action. Bloomsbury Academic: London, United Kingdom.

Ehlers, U. D. (2013). Open Learning Cultures. A Guide to Quality, Evaluation, and Assessment for Future Learning. Heidelberg: Springer-Verlag Berlin Heidelberg.

Felder, R., \& Brent, R. (2016). Teaching and Learning STEM. A Practical Guide. NY: J. Wiley \& Sons, Inc.

Gaucaite, R., Kazlauskiene, A., \& Poceviciene, R. (2012). Savivaldaus mokymosi, orientuoto i inovatyvius sprendimus, sistema. Siauliai: VsI Siauliu universiteto leidykla.

Good School Concept (2015). Retrieved from https://www.e-tar.lt/portal/lt/legalAct/ f2f65120a7bb11e5be7fbe3f919a1ebe

Gros, B., Kinshuk, \& Maina, M. (Eds.). (2016). The Future of Ubiquitous Learning: Learning Designs for Emerging Pedagogies. Heidelberg: Springer Berlin Heidelberg.

Hattie, J. (2009). Visible Learning. A Synthesis of over 800 Meta-Analyses Relating to Achievement. London: Routledge.

Helmke, A. (2010). Unterrichtsqualität und Lehrerprofessionalität. Diagnose, Evaluation und Verbesserung des Unterrichts. Seelze: Klett-Kallmeyer.

Kazlauskiene, A., Masiliauskiene, E., Gaucaite, R., \& Poceviciene, R. (2010). Organization of Self-Directed Learning as Educational Innovation: the Context of the Bologna Process. Teacher Education, 15(2), 95-111.

Kapitulčinova, D., Dlouhá, J., Ryan, A., Barton, A., Dlouhý, J., Mader, M., et al. (Eds.). (2015). Leading Practice Publication: Professional Development of University Educators on Education for Sustainable Development in European Countries. Prague: Charles University.

LR Law on Education. (2011). [LR Švietimo įstatymas]. Retrieved from https://www.etar.lt/portal/lt/legalAct/TAR.E2EBE95E7723

Mayring, P. (2014). Qualitative Content Analysis Theoretical Foundation, Basic Procedures and Software Solution. Austria: Klagenfurt. 
Mullis, I.V.S., \& Martin, M.O. (Eds.). (2015). TIMSS 2015 Assessment Frameworks. Chestnut Hill, MA: TIMSS \& PIRLS International Study Center, Boston College. National Progress Strategy “Lithuania 2030”. LR Parliament. 2012-05-15, nr. XI-2015. Retrieved from https://lrv.lt/uploads/main/documents/files/EN_version/Useful_ information/lithuania2030.pdf

Mullis, I.V.S., \& Martin, M.O. (Eds.). (2013). PIRLS 2016 Assessment Framework, 2nd edition. Chestnut Hill, MA: TIMSS \& PIRLS International Study Center, Boston College.

Pipere, A., Salite, I., \& Veisson, M. (2015). Developing research in teacher education for sustainability: UN DESD via the Journal of Teacher Education for Sustainability. Journal of Teacher Education for Sustainability, 17(2), 5-43.

Quality of Activity of General Education Schools. (2015). [Bendrojo ugdymo mokyklu veiklos kokybej]. Retrieved from http:/www.nmva.smm.lt/wp-content/uploads/ 2012/12/Metinis-prane\% C5\%A1imas-maketas-02.04.pdf

Delors, J., Al.Mufti, I., Amagi, I., Carneiro, R., Chung, F., et al. (1996). Learning: The Treasure within - Report to UNESCO of the International Commission on Education for the Twenty-first Century. Paris: UNESCO Publishing. Retrieved from http://www.unesco.org/education/pdf/15_62.pdf.

Rethinking Education: Investing in Skills for Better Socio-Economic Outcomes. (2012). Communication from the Commission to the European Parliament, the Council, the European Economic and Social Committee and the Committee of the Regions. COM/2012/0669 final. Retrieved from http://eur-lex.europa.eu/legal-content/EN/ TXT/?qid=1389776578033\&uri=CELEX:52012DC0669

Rithie, J., \& Lewis, J. (2003). Qualitative Research Practice. A Guide for Social Science Students and Researchers. London: Thousand Oaks.

Shewbridge, C., Godfrey, K., Hermann, Z., \& Nusche, D. (2016). OECD Reviews of School Resources: Lithuania 2016. Paris: OECD Publishing.

Stronge, J. H. (2010). Effective Teachers = Student Achievement: What the Research Says. New York: Routledge.

The Teaching and Learning Toolkit. (2014). An Accessible Summary of Educational Research on Teaching 5-16 Year Olds. Retrieved from https://educationendowment foundation.org.uk/toolkit/toolkit-a-z/

Thomas, D., \& Brown, J. S. (2011). A new culture of learning: Cultivating the imagination for a world of constant change. United States: Create Space Independent Publishing Platform.

Tilbury, D. \& Mulà, I. (2009). Review of Education for Sustainable Development Policies from a Cultural Diversity and Intercultural Dialogue: Gaps and Opportunities for Future Action. Paris: UNESCO. Retrieved from http://unesdoc.unesco.org/images/ 0021/002117/211750e.pdf

Tilbury, D. (2011) Education for Sustainable Development: An Expert Review of Processes and Learning. Paris: UNESCO. Retrieved from http://unesdoc.unesco.org/ images/0019/001914/191442e.pdf

Tiwana, A. (2002). The knowledge management toolkit: Orchestrating IT, strategy and knowledge platform. 2nd ed., Upper Saddle River: Prentice Hall.

Trilling, B., \& Fadel, C. (2009). 21st century skills: Learning for life in our times. San Franciso, CA: Jossey-Bass. 
Turner, D. W. (2010). Qualitative interview design: A practical guide for novice investigators. The Qualitative Report, 15, 754-760. Retrieved from http://www. nova.edu/ssss/QR/QR15-3/qid.pdf

The National Strategy on Education for the Years 2013-2022. [Valstybine švietimo 2013-2022 metų strategija]. Lietuvos Respublikos Seimas, 2013 m. gruodžio 23 d. Nr. XII-745. Retrieved from http://www3.lrs.lt/pls/inter3/dokpaieska.showdoc_1? p_id $=463390$

van Velzen, J. (2016). Metacognitive learning. Advancing learning by developing general knowledge of learning process. Springer International Publishing.

Correspondence concerning this paper should be addressed to prof. Dr. Ausra Kazlauskiene, Siauliai University, P. Visinskio St. 25, Siauliai. Email: akazlauskiene@yahoo.com 